\section{Evaluation of Irrigation Frequency and Quantity on Leaf Gas Exchange, Growth, and Nitrate Leaching of Coleus in a Simulated Landscape}

\author{
S.M. Scheiber ${ }^{1,5}$, R.C. Beeson, Jr. ${ }^{2}$, J. Chen ${ }^{2}$, \\ Q. Wang ${ }^{3}$, and B. Pearson ${ }^{4}$ \\ University of Florida, IFAS, Environmental Horticulture Department, \\ MREC, 2725 Binion Road, Apopka, FL 32703
}

Additional index words. drainage lysimeter, landscape irrigation, application quantity, water management, Solenostemon scutellarioides, bedding plants

\begin{abstract}
Solenostemon scutellarioides (coleus) were grown in drainage lysimeters in concurrent experiments to evaluate effects of irrigation quantity and frequency on growth responses, leaf gas exchange, and nitrate leaching. Lysimeters in Expt. 1 were irrigated either with $13 \mathrm{~mm}$ daily or $13 \mathrm{~mm}$ every other day. Daily irrigation increased mean leachate and doubled nitrate leached compared with every other day $\left(22.9 \mathrm{~kg} \cdot \mathrm{ha}^{-1}\right.$ $\mathrm{N}$ versus $10.8 \mathrm{~kg} \cdot \mathrm{ha}^{-1} \mathrm{~N}$, respectively). In Expt. 2, lysimeters were irrigated every 2 days with $13 \mathrm{~mm}$ or every 3 days with $18 \mathrm{~mm}$ such that total depth applied was equivalent. Irrigation frequency had no effect on irrigation quantity or nitrate leached. In these experiments, assimilation rates, stomatal conductance, and transpiration rates were influenced by day since irrigation with values lower on days without irrigation. However, neither irrigation quantity nor frequency affected final shoot dry weight, root dry weight, height or growth indices $(P>0.05)$.
\end{abstract}

Contamination of groundwater supplies with nitrates from agricultural endeavors has been a concern for decades. Booming residential and commercial development has turned attention to nitrate leaching from commercial and residential lawns (Campbell and Sargent, 2002). Nitrate leaching from turfgrass has been widely researched, and increased nitrogen losses after irrigation have been reported (Brown et al., 1977; Morton et al., 1988; Snyder et al., 1984). However, few studies have examined nitrogen losses from newly planted or established landscapes (Erickson et al., 2001; Geron et al., 1993; Gross et al., 1990). Annual flower beds are an intensely managed portion of the landscape that require frequent applications of water and fertilizer and provide an additional origin for nonpoint source pollution (Campbell and Sargent, 2002).

Despite regulations aimed at water conservation and reductions in nonpoint source pollution, water management districts within Florida regulate irrigation frequency but not application volumes. Thus, total volume

Received for publication 18 June 2007. Accepted for publication 14 Dec. 2007.

This work was supported by the Florida Agricultural Experiment Station and approved for publication.

${ }^{1}$ Assistant Professor.

${ }^{2}$ Associate Professor.

${ }^{3}$ Post doc.

${ }^{4}$ Biological Scientist.

${ }^{5}$ To whom reprint requests should be addressed; e-mail scheiber@ufl.edu applied can vary in magnitude and potentially result in overirrigation. Several studies conducted on trees, shrubs, and herbaceous perennials have demonstrated that irrigation frequency affects growth in the landscape. Aesthetic quality and shoot or root dry weight decreased for several perennial species as irrigation frequency declined from weekly to every 4 weeks (Zollinger et al., 2006). During landscape establishment, canopy size and dry weight of Viburnum odoratissimum KerGawl (sweet viburnum) increased as irrigation frequency increased from once every $4 \mathrm{~d}$ to $2 \mathrm{~d}$ (Scheiber et al., 2007). Gilman et al. (1998) reported frequent irrigation of Quercus virginiana Mill. (Live oak) accelerated establishment in comparison with trees irrigated infrequently. Irrigation quantities in these studies were not changed during the experiments.

Many investigations into irrigation and plant establishment applied equivalent volumes at each irrigation. Such methods make discernment between effects of irrigation frequency and quantity on growth difficult. To make the distinction, Paine et al. (1992) and Stabler and Martin (2000) applied equivalent total volumes at different frequencies using reference evapotranspiration. Paine et al. (1992) reported irrigation frequency had no effect on mortality rates or aesthetic quality of several woody ornamentals. Stabler and Martin (2000) found increased irrigation frequency increased growth but decreased water use efficiency.

The objectives of this study were to: 1) evaluate growth responses and leaf gas exchange of the annual bedding plant coleus in relation to irrigation frequency and quantity, 2) develop and examine water budgets for each irrigation regime, and 3) determine leaching potential of nitrates from fertilizeramended annual flower beds in response to various irrigation frequencies and quantities.

\section{Materials and Methods}

Two experiments were conducted concurrently to determine effects of irrigation quantity and irrigation frequency on shoot and root growth, actual evapotranspiration, and nitrate leaching from simulated landscape beds of Solenostemon scutellarioides (L.) Codd 'Yalaha' (coleus). Plants were obtained from a commercial nursery in 0.72 -L containers with six transplanted on 8 Aug. 2002 into each drainage lysimeter constructed from 246-L rigid plastic containers (Lerio Corp., Kissimmee, FL) placed in full sun. Each lysimeter had a diameter of $0.89 \mathrm{~m}$ and a depth of $0.44 \mathrm{~m}$ and contained six plants. Lysimeters were backfilled with native top soil (Apopka fine sand) to simulate landscape conditions. Each lysimeter was elevated $0.5 \mathrm{~m}$ aboveground to facilitate drainage into $38-\mathrm{L}$ opaque polyethylene boxes with lids. Each drainage container was completely enclosed to prevent evaporation and dilution by nonleachate rainfall. To minimize impact of solar radiation on root zone temperatures, exteriors of lysimeters were painted with white exterior flat latex (Enterprise Paint Co., Wheeling, IL). Plantings were managed in accordance with recommended practices for bedding plants in Florida (Black and Gilman, 1998). This included daily irrigation at $13 \mathrm{~mm}$ until plant establishment and use of controlledrelease fertilizer. Controlled-release fertilizer (Osmocote 18N-2.6P-9.9K; The Scotts Co., Marysville, $\mathrm{OH}$ ) was uniformly broadcast at a standard rate of $1.68 \mathrm{~kg} \mathrm{~N} / 100 \mathrm{~m}^{2}$ ( $58 \mathrm{~g}$ per lysimeter) immediately after transplanting.

Expt. 1: Irrigation quantity. All lysimeters were irrigated as recommended (Black and Gilman, 1998) for $14 \mathrm{~d}$ after transplanting before implementing one of two irrigation regimes: $13 \mathrm{~mm}$ daily or $13 \mathrm{~mm}$ every other day. Irrigation rates were designed to impose minimum and elevated water stress levels, respectively, on plants in lysimeters over each $2 \mathrm{~d}$ period.

Expt. 2. All lysimeters were irrigated as described previously for $14 \mathrm{~d}$ after transplanting before implementing one of two irrigation frequencies: $13 \mathrm{~mm}$ every second day or $18 \mathrm{~mm}$ every third day. At the stated rates, equivalent quantities were applied every $6 \mathrm{~d}$. Irrigation frequencies were designed to impose what were termed minimum, elevated, and severe water stress levels beginning the day of irrigation on plants in lysimeters irrigated every 3 d. Similarly, minimum and severe stress levels were imposed on plants in lysimeters irrigated every $2 \mathrm{~d}$.

Each lysimeter was irrigated independently as a separate zone controlled by an automated irrigation time clock (Raindial; Hardee Irrigation, Laguna Niquel, CA). Each 
lysimeter was placed between two overhead impact sprinklers (Model 532; RainBird, San Diego, CA) situated diagonally across from each other $8.7 \mathrm{~m}$ apart and mounted $1.5 \mathrm{~m}$ aboveground level. A lysimeter was placed between a pair of sprinklers where the Christiansen Coefficient of Uniformity (Haman et al., 2005) was a minimum of 0.93. Irrigations began at $0500 \mathrm{HR}$ and were completed by $0700 \mathrm{HR}$ each day independent of rain events. Flow meters (Model C700TP; ABS, Ocala, FL) were installed for each zone to record irrigation volumes. Meter gallonage was recorded every morning during the experiment. Irrigation applied was calculated by multiplying meter readings by the percentage of water that fell within the area occupied by the lysimeter determined from data collected during calibration of each pad.

Leachate collection and nitrate analysis. Leachate volume was recorded daily for both experiments with subsamples collected daily for analysis of nitrate-N. Samples were analyzed for nitrate-N using a spectrophotometer as described by Diatloff and Rengel (2001). Actual evapotranspiration $\left(\mathrm{ET}_{\mathrm{A}}\right)$ was calculated by subtracting collected leachate volume from total volume applied (irrigation + precipitation) for each irrigation period.

Growth indices and biomass. Average canopy height, widest canopy width, and width perpendicular to widest width were recorded for each plant in Expts. 1 and 2 to calculate growth indices (growth index = height $\times$ width $1 \times$ width 2 ). All plants were measured immediately after transplanting and at harvest. At harvest, shoots were severed at the soil line and dried at $65{ }^{\circ} \mathrm{C}$ until constant dry weight was obtained. To obtain root dry weight, each lysimeter was subsampled as a single pie-shaped wedge such that one-sixth of the soil volume was removed and original plant root balls were proportionally represented. Soil was removed from roots, and roots were dried as described for shoots. Total root mass was calculated by multiplying measured root mass by 6 .

Leaf gas exchange measurements. Gas exchange measurements for both experiments began at $1000 \mathrm{HR}, 1300 \mathrm{HR}$, and 1600 HR for $\approx 1$-hour periods on the day before irrigation (maximum stress day) and the day of irrigation (minimum stress day) for 3 weeks toward the end of the experiment. Measurements were taken on two leaves in each lysimeter during each sampling period. Chosen leaves were fully expanded and recently matured, generally $\approx 200 \mathrm{~mm}$ below a stem's apex. Leaf gas exchange measurements were recorded with an open-system portable infrared gas analyzer (LCI Portable Photosynthesis System; ADC BioScientific Ltd., Hoddesdon, Herts, UK). Daily cumulative assimilation and daily cumulative transpiration were calculated for each lysimeter in a manner consistent with the calculation of water stress intervals (Beeson, 1992; Schulze et al., 1980). In brief, areas under curves generated from mean period values for each lysimeter for daily assimilation and transpiration rates were integrated assuming both photosynthesis and transpiration were zero at dawn and sunset. Changes in rates between measurements were also assumed to be linear between one point to the next (Scheiber and Beeson, 2006). Cumulative daily estimates of assimilation and transpiration were sorted by sampling week before analysis to reduce the effect of daylength.

Landscape quality. Landscape quality, based on aesthetic appearance, was rated monthly by three subjects on a scale of 1 (dead) to 5 (mounded, proportional form; dense; complete coverage, no dieback). Ratings were averaged across subjects.

Data analysis. Expts. 1 and 2 were conducted as randomized complete block designs with three blocks of single lysimeter replicates. For each experiment, all three blocks contained both irrigation regimes for a total of six lysimeters. Lysimeters irrigated every $2 \mathrm{~d}$ served as the control for both experiments. Thus, the combined total of lysimeters for Expts. 1 and 2 equaled nine.

Data for experiments were analyzed independently. Growth data, consisting of growth index, shoot dry weight, root dry weight, total biomass, and shoot to root ratios, were analyzed by GLM with two irrigation treatments and three replications. Cumulative leachate volume and nitrates were similarly analyzed using GLM. Daily cumulative assimilation (A) and transpiration (E) values were analyzed separately by week as repeated measures using a split plot design with irrigation treatment as the main plot and day of water stress level as a subplot (Snedecor and Cochran, 1980). Stomatal conductance $\left(g_{\mathrm{S}}\right)$ was averaged for each sampling day and analyzed as repeated measures using a split plot design with irrigation treatment as the main plot and day of water stress level as a subplot. For irrigation frequency, the day without irrigation of the 2-d treatment was compared with its equivalent (maximum stress day) of the 3-d frequency. Landscape quality was analyzed by NPAR1WAY Wilcoxon Kruskal-Wallis. Where differences in landscape quality were indicated, means separation was by Wilcoxon two-sample test (Howell, 2004). All analysis was conducted using SAS (Version 9.1.3; SAS Institute, Cary, NC). Where significant differences were indicated, mean separation was by Fisher's protected least significance differences at $P=0.05$ (Snedecor and Cochran, 1980).

\section{Results and Discussion}

\section{Expt. 1: Quantity}

Leaf gas exchange measurement. The first sampling week (53 d after transplanting), irrigation quantity had little impact $(P>$ 0.05 ) on daily cumulative assimilation (A) or $g_{\mathrm{S}}$. However, daily irrigation increased cumulative transpiration rates (E; 210 $\left.\mathrm{mol} \cdot \mathrm{m}^{-2} ; P<0.01\right)$ compared with irrigation applied every $2 \mathrm{~d}\left(147.5 \mathrm{~mol} \cdot \mathrm{m}^{-2}\right)$. Thereafter, $\mathrm{A}, \mathrm{E}$, and $\mathrm{g}_{\mathrm{s}}$ were similar $(P>0.05)$ between daily and 2-d irrigation for all sampling cycles. This contrasts with the results of Pattanagul and Madore (1999) who reported declines in leaf gas exchange for Coleus blumei Benth. when drought stress reduced leaf water content from $80 \%$ to $60 \%$. This suggests the 2-d irrigation supplied sufficient volume to prevent significant declines in leaf water content given the large soil volumes and landscape-like conditions of the lysimeters. Throughout the experiment, E, A, and $g_{\mathrm{S}}$ ranged from 210.0 to $258.9 \mathrm{~mol} \cdot \mathrm{m}^{-2}, 0.118$ to $0.165 \mathrm{~mol} \cdot \mathrm{m}^{-2}$, and 0.36 to $0.44 \mathrm{~mol} \cdot \mathrm{m}^{-2} \cdot \mathrm{s}^{-1}$, respectively, for lysimeters irrigated daily. For lysimeters irrigated every $2 \mathrm{~d}, \mathrm{E}, \mathrm{A}$, and $g_{\mathrm{S}}$ ranged from 112.5 to $215.2 \mathrm{~mol} \cdot \mathrm{m}^{-2}, 0.089$ to 0.171 $\mathrm{mol} \cdot \mathrm{m}^{-2}$, and 0.14 to $0.38 \mathrm{~mol} \cdot \mathrm{m}^{-2} \cdot \mathrm{s}^{-1}$, respectively. On elevated stress days, E, A, and $g_{\mathrm{S}}$ tended to decreased by at least $24 \%$, $10 \%$, and $23 \%$, respectively (data not shown).

Biomass and leachate. Equivalent rates of $\mathrm{A}, \mathrm{E}$, and $g_{\mathrm{S}}$ are reflected in similar $(P>0.05)$ shoot dry weight (532.8 $\mathrm{g} \pm 72.6)$, root dry weight $(89.1 \mathrm{~g} \pm 16.5)$, total biomass $(621.9 \mathrm{~g}$ $\pm 81.6)$, canopy growth index $\left(0.35 \mathrm{~m}^{3} \pm\right.$ $0.01)$, and shoot-to-root ratios $(6.10 \pm 1.04)$ between lysimeters irrigated daily and lysimeters receiving irrigation every $2 \mathrm{~d}$. Rainfall likely had limited impact on these results. Rain occurred only eight times on nonirrigated days, which accounted for $80 \mathrm{~L}$ of the $238 \mathrm{~L}$ total rainfall per lysimeter. Of this, only $35 \%, 28 \mathrm{~L}$ or $45 \mathrm{~mm}$ of additional water occurred on nonirrigation days during the last 7 weeks of the experiments. Rain falling on irrigation days added little if any additional water to the lysimeters because each irrigation without rainfall resulted in leachate collection.

Over the course of this experiment, mean daily leachate volumes of $5.01 \mathrm{~L}$ from daily irrigation were larger than the $3.16 \mathrm{~L}$ for 2$\mathrm{d}$ irrigations, resulting in a $59 \%$ increase in mean total leachate volumes $(P<0.01)$ for daily irrigation (Table 1$)$. Total mean irrigation volume received by the daily irrigation regime $(570 \mathrm{~L})$ was greater $(P<0.001)$ than the 2 -d regime by $303 \mathrm{~L}$ resulting in higher cumulative $\mathrm{ET}_{\mathrm{A}}$ with daily irrigation (Table 1). A mean total of $918 \mathrm{~mm}$ of irrigation was applied to the daily treatment versus $430 \mathrm{~mm}$ applied to the 2-d treatment. In addition, rainfall added another $380 \mathrm{~mm}$ to each lysimeter. Higher irrigation quantity from daily irrigation resulted in lower harvested dry biomass per liter of water applied $(0.80$ $\left.\mathrm{g} \cdot \mathrm{L}^{-1} ; P<0.01\right)$ compared with the 2 -d irrigation regime $\left(2.07 \mathrm{~g} \cdot \mathrm{L}^{-1}\right)$. However, irrigation efficiency was similar $(P>0.05$; Table 1).

Once irrigation treatments were imposed, mean daily leachate nitrate concentrations were similar $(P>0.05)$ between daily $(4.51$ $\left.\mathrm{mg} \cdot \mathrm{L}^{-1}\right)$ and 2-d irrigations (4.41 $\left.\mathrm{mg} \cdot \mathrm{L}^{-1}\right)$; however, daily irrigation resulted in a twofold increase $(P<0.01)$ in total nitrates leached (Table 1). Quantifying nitrate leaching as a function of irrigation quantity has not been previously reported for bedding plants in landscape. However, similar effects as 
those presented here have been reported for turfgrasses. Morton et al. (1988) reported leaching of $32 \mathrm{~kg} \cdot \mathrm{ha}^{-1}$ from Poa pratensis L. (Kentucky bluegrass) in home lawns after $\mathrm{N}$ applications of $244 \mathrm{~kg} \cdot \mathrm{ha}^{-1}$ combined with overwatering with $37.5 \mathrm{~mm}$ of water per week in addition to rainfall. Total mean nitrate leaching from daily irrigation of coleus was $36.3 \mathrm{~kg} \cdot \mathrm{ha}^{-1}$. A study on Bermuda grass (Cynodon dactylon L.) observed two- to 28 -fold increases in nitrate losses as a result of increasing irrigation application quantity (Snyder et al., 1984). Brown et al. (1977) found that irrigation quantity had no significant effect on nitrate leaching from golf greens when $\mathrm{N}$ application rates were low. However, when a high, single $\mathrm{N}$ application rate of $163 \mathrm{~kg} \cdot \mathrm{ha}^{-1} \mathrm{~N}$ was examined with medium to high irrigation quantities of 8 to $12 \mathrm{~mm} \cdot \mathrm{d}^{-1}$, substantial increases in nitrate leaching were observed. Total nitrate leaching from lysimeters by daily irrigation and rainfall accounted for $13 \%$ of total $\mathrm{N}$ applied versus $6 \%$ for the $2-\mathrm{d}$ irrigation treatment over the $76 \mathrm{~d}$ of this experiment. A study examining the interactive effects of irrigation and $\mathrm{N}$ source on Cynodon dactylon $\mathrm{L}$. observed nitrate leaching ranging from $0.3 \%$ to $56 \%$ of total $\mathrm{N}$ applied in conjunction with increasing irrigation volumes (Snyder et al., 1984).

\section{Expt. 2: Frequency}

Leaf gas exchange measurement. Daily A, $\mathrm{E}$, and $g_{\mathrm{S}}$ were not influenced by irrigation frequency $(P>0.05$; data not shown), nor was the interaction between irrigation frequency and stress day significant $(P>0.05)$. However, similar to Expt. 1, stress day influenced leaf gas exchange (Table 2). During the second and third sampling periods, stress day affected E. Transpiration decreased $(P<0.05)$ in conjunction with increasing stress day (Table 2) with 64\% and $32 \%$ reductions in $\mathrm{E}$ during the second and third sampling periods, respectively. Similar results were found for $\mathrm{g}_{\mathrm{s}}$ during the second sampling period (Table 2) with $g_{\mathrm{S}}$ declining $72 \%$ between irrigation day (minimum stress) and the day before irrigation (maximum stress).

Biomass and leachate. Shoot dry weight $(580 \mathrm{~g})$ and canopy size $\left(0.34 \mathrm{~m}^{3}\right)$ were identical for 2- and 3-d irrigation frequencies. Irrigation applied at 2- and 3-d intervals had no effect $(P>0.05)$ on root dry weight $(84.4 \mathrm{~g}$ $\pm 12.1)$, total biomass $(664.5 \mathrm{~g} \pm 27.1)$, or shoot-to-root ratios $(7.01 \pm 1.23)$. Paine et al. (1992) reported irrigation frequencies of daily and every 3,5 , and $7 \mathrm{~d}$ had no effect $(P>0.5)$ on woody shrub growth or visual rating when total irrigation volume was the same. Similar dry weight among frequent and infrequent irrigation regimes was also reported for Caesalpinia pulcherrima L. (Red bird of paradise), but not for Cercidium floridum Benth. Ex A. Gray (blue palo verde; Stabler and Martin, 2000). Prevete et al. (2000) reported similar results as coleus for Rudbeckia triloba L. (Mexican petunia). Assimilation, E, and $g_{\mathrm{S}}$ were reduced after exposure to drought cycles of 2, 4 , or 6 $\mathrm{d}$ (stress level days); however, treatments had no effect on growth indices or dry weight of Rudbeckia.

Total mean irrigation quantities received throughout the experiment were similar $(P>$ 0.05 ) between irrigation frequencies (Table $3)$ resulting in similar $(P>0.05)$ harvested dry biomass per liter of water applied for 2$\mathrm{d}\left(2.07 \mathrm{~g} \cdot \mathrm{L}^{-1}\right)$ and $3-\mathrm{d}\left(1.73 \mathrm{~g} \cdot \mathrm{L}^{-1}\right)$ frequencies. Total leachate volumes were similar between 2-d and 3-d frequencies and differed only by $4 \mathrm{~L}$ (Table 3 ). Consequently, mean $\mathrm{ET}_{\mathrm{A}}$ and irrigation efficiency (Table 3 ) were also similar $(P>0.05)$.

After implementation of irrigation regimes, mean daily nitrate concentrations and total nitrates leached were similar $(P>0.05)$ for the 2-d (4.41 mg. $\left.\mathrm{L}^{-1} ; 0.67 \mathrm{~g}\right)$ and $3-\mathrm{d}$ $\left(5.61 \mathrm{mg} \cdot \mathrm{L}^{-1} ; 0.77 \mathrm{~g}\right)$ frequencies (Table 3 ). Total nitrate leaching from the 3-d irrigation regime and rainfall accounted for $8 \%$ of total $\mathrm{N}$ applied over the entire experiment.

Most Florida water management districts permit daily irrigation for 30 to $60 \mathrm{~d}$ after transplant followed by application frequencies for overhead irrigation ranging from weekly to three times per week dependent on municipality and severity of drought conditions. However, our data indicate growth and leaf gas exchange were similar between coleus irrigated daily or every $2 \mathrm{~d}$ beginning $14 \mathrm{~d}$ after transplanting. In addition, irrigation volume did not influence

Table 1. Water balance and leaching potential of two application quantities (13 mm daily and $13 \mathrm{~mm}$ every $2 \mathrm{~d}$ ) for coleus over a 76-d period (transplant to harvest) and 62-d period (after treatment initiation) during late summer to early winter in central Florida. ${ }^{\mathrm{z}}$

\begin{tabular}{|c|c|c|c|c|c|c|}
\hline Treatment & $\begin{array}{l}\text { Cumulative } \\
\text { irrigation } \\
\text { (L) }\end{array}$ & $\begin{array}{c}\text { Total } \\
\text { water input } \\
\text { (L) }\end{array}$ & $\begin{array}{l}\text { Leachate } \\
\text { volume } \\
\text { (L) }\end{array}$ & $\begin{array}{c}\text { Cumulative } \\
\mathrm{ET}_{\mathrm{A}} \\
\text { (L) }\end{array}$ & $\begin{array}{l}\text { Irrigation } \\
\text { efficiency }\end{array}$ & $\begin{array}{l}\text { Total } \mathrm{NO}_{3} \\
\text { leached }(\mathrm{g})\end{array}$ \\
\hline \multicolumn{7}{|c|}{ Transplant to harvest (76 d) } \\
\hline Daily & $569.9 \mathrm{a}^{\mathrm{xw}}$ & $807.8 \mathrm{a}$ & $380.9 \mathrm{a}$ & $426.8 \mathrm{a}$ & $0.53 \mathrm{a}$ & $2.25 \mathrm{a}$ \\
\hline $2-d$ & $267.3 \mathrm{~b}$ & $505.2 \mathrm{~b}$ & $239.8 \mathrm{~b}$ & $264.5 \mathrm{~b}$ & $0.52 \mathrm{a}$ & $1.41 \mathrm{~b}$ \\
\hline \multicolumn{7}{|c|}{ Posttreatment initiation (62 d) } \\
\hline Daily & $494.8 \mathrm{a}^{\mathrm{xw}}$ & $694.1 \mathrm{a}$ & $282.9 \mathrm{a}$ & $411.2 \mathrm{a}$ & $0.59 \mathrm{a}$ & $1.27 \mathrm{a}$ \\
\hline $2-d$ & $206.9 \mathrm{~b}$ & $404.4 \mathrm{~b}$ & $151.3 \mathrm{~b}$ & $253.1 \mathrm{~b}$ & $0.63 \mathrm{a}$ & $0.67 \mathrm{~b}$ \\
\hline
\end{tabular}

${ }^{\mathrm{z}}$ Each treatment was applied to a drainage lysimeter with a surface area of $0.62 \mathrm{~m}^{2}$ containing six plants each.

${ }^{\mathrm{y}}$ Irrigation efficiency $=$ cumulative $\mathrm{ET}_{\mathrm{A}} /$ total water input.

${ }^{\mathrm{x}}$ Means representative of three lysimeter replicates.

"Means separations within columns and time periods using Fisher's protected least significant difference $(P<0.05)$.

Table 2. Leaf gas exchange for two irrigation frequencies (13 mm every $2 \mathrm{~d}$ and $18 \mathrm{~mm}$ every $3 \mathrm{~d})$ that applied the same cumulative volume every $6 \mathrm{~d} .^{\mathrm{z}}$

\begin{tabular}{llccc}
\hline \multirow{2}{*}{$\begin{array}{l}\text { Sampling } \\
\text { period }\end{array}$} & $\begin{array}{l}\text { Stress level } \\
\text { day }\end{array}$ & \multicolumn{3}{c}{ Leaf gas exchange parameter } \\
\cline { 3 - 5 } & Minimum & $0.143 \mathrm{a}^{\mathrm{yx}}$ & $\mathrm{E}\left(\mathrm{mol} \cdot \mathrm{m}^{-2}\right)$ & $g_{\mathrm{S}}\left(\mathrm{mol}^{-2} \cdot \mathrm{m}^{-2}\right)$ \\
\hline 1 & Maximum & $0.092 \mathrm{a}$ & $157.0 \mathrm{a}$ & $0.387 \mathrm{a}$ \\
& Minimum & $0.187 \mathrm{a}$ & $182.2 \mathrm{a}$ & $0.280 \mathrm{a}$ \\
& Maximum & $0.089 \mathrm{a}$ & $190.5 \mathrm{a}$ & $0.223 \mathrm{a}$ \\
3 & Minimum & $0.185 \mathrm{a}$ & $68.8 \mathrm{~b}$ & $0.062 \mathrm{~b}$ \\
& Maximum & $0.187 \mathrm{a}$ & $289.7 \mathrm{a}$ & $0.460 \mathrm{a}$ \\
& & $196.4 \mathrm{~b}$ & $0.312 \mathrm{a}$ \\
\hline
\end{tabular}

${ }^{z}$ Values for assimilation (A) and transpiration (E) are cumulative daily totals based on integration of periodic measurements from sunrise to sunset. Stomatal conductance $\left(g_{\mathrm{S}}\right)$ values are the daily mean of six leaves per replication. All values were calculated for minimum (day of irrigation) and maximum (day just before irrigation) stress days for each sampling period.

y Means representative of three lysimeter replicates.

${ }^{\mathrm{x}}$ Mean separations within columns for each sampling period using Fisher's protected least significant difference $(P<0.05)$.

Table 3. Water balance and leaching potential of two application frequencies (13 mm every $2 \mathrm{~d}$ and $18 \mathrm{~mm}$ every $3 \mathrm{~d}$ ) over a 76-d period (transplant to harvest) and 62-d period (after treatment initiation) during late summer to early winter in central Florida. ${ }^{\mathrm{z}}$

\begin{tabular}{|c|c|c|c|c|c|c|}
\hline Treatment & $\begin{array}{l}\text { Cumulative } \\
\text { irrigation (L) }\end{array}$ & $\begin{array}{c}\text { Total water } \\
\text { input (L) }\end{array}$ & $\begin{array}{c}\text { Leachate } \\
\text { volume (L) }\end{array}$ & $\begin{array}{c}\text { Cumulative } \\
\mathrm{ET}_{\mathrm{A}}(\mathrm{L})\end{array}$ & $\begin{array}{l}\text { Irrigation } \\
\text { efficiency }\end{array}$ & $\begin{array}{l}\text { Total } \mathrm{NO}_{3} \\
\text { leached }(\mathrm{g})\end{array}$ \\
\hline \multicolumn{7}{|c|}{ Transplant to harvest (76 d) } \\
\hline $2-d$ & $267.3 \mathrm{a}^{\mathrm{xw}}$ & $505.2 \mathrm{a}$ & $239.8 \mathrm{a}$ & $264.5 \mathrm{a}$ & $0.52 \mathrm{a}$ & $1.41 \mathrm{a}$ \\
\hline $3-d$ & $315.9 \mathrm{a}$ & $553.8 \mathrm{a}$ & $235.8 \mathrm{a}$ & $318.0 \mathrm{a}$ & $0.57 \mathrm{a}$ & $1.54 \mathrm{a}$ \\
\hline \multicolumn{7}{|c|}{ Posttreatment initiation (62 d) } \\
\hline $2-d$ & $206.9 \mathrm{a}^{\mathrm{xw}}$ & $404.4 \mathrm{~b}$ & $151.3 \mathrm{a}$ & $253.1 \mathrm{~b}$ & $0.63 \mathrm{a}$ & $0.67 \mathrm{a}$ \\
\hline $3-d$ & $237.3 \mathrm{a}$ & $438.2 \mathrm{a}$ & $136.7 \mathrm{a}$ & $301.5 \mathrm{a}$ & $0.69 \mathrm{a}$ & $0.77 \mathrm{a}$ \\
\hline
\end{tabular}

${ }^{\mathrm{z}}$ Each treatment was applied to a drainage lysimeter with a surface area of $0.62 \mathrm{~m}^{2}$ containing six plants each.

${ }^{\mathrm{y}}$ Irrigation efficiency $=$ cumulative $\mathrm{ET}_{\mathrm{A}} /$ total water input

${ }^{\mathrm{x}}$ Means representative of three lysimeter replicates.

${ }^{\text {w}}$ Mean separations within columns using Fisher's protected least significant difference $(P<0.05)$. 
aesthetic quality $(P>0.05$; data not shown). When equivalent volumes were applied at 2or 3-d intervals, no impact on growth or leaf gas exchange was found. Similar to Expt. 1, aesthetic quality was similar $(P>0.05)$ between irrigation frequencies (data not shown). Daily irrigation resulted in overirrigation by $116 \%$ and a twofold increase in total nitrates leached compared with similar landscape performance of every 2-d irrigation.

Current recommendations for annual flower beds in Florida advise applying 13 $\mathrm{mm}$ of irrigation daily during establishment with irrigation applied "as needed" during the maintenance phase. Landscape irrigation recommendations often lack scientific merit being based primarily on anecdotal data (Garcia-Navarro et al., 2004; White et al., 2004), and establishment rates are not clearly defined. Thus, landscape professionals and homeowners are faced with the task of scheduling irrigation despite a lack of information and understanding of plant water needs. This lack of information combined with failures to reset automated time clocks after establishment often results in overirrigation (Dukes et al., 2005). Dependent on location and source, overirrigation in urban landscapes is estimated at $16 \%$ to $40 \%$ (Cotter and Chavez, 1979; Dukes et al., 2005). The results from these experiments indicate that coleus of equivalent size and quality resulting from daily irrigation can be obtained with half the irrigation quantity (every $2 \mathrm{~d}$ irrigation), reducing negative environmental impacts from nitrogen depletion and potential contamination of groundwater supplies. Furthermore, irrigation can be applied at 2- or 3-d intervals provided total application volumes are equivalent, although without any additional reduction in nitrate leaching from the 3 -d interval. Taken together, these experiments suggest acceptable aesthetic quality and size can be obtained for coleus in landscapes under temperate conditions irrigated every $3 \mathrm{~d}$ with $18 \mathrm{~mm}$ per event.

\section{Literature Cited}

Beeson, R.C. 1992. Restricting overhead irrigation to dawn limits growth in container-grown woody ornamentals. HortScience 27:996-999.

Black, R.J. and E.J. Gilman. 1998. Your Florida guide to bedding plants: Selection, establishment, and maintenance. University Press of Florida, Gainesville, FL.

Brown, K.W., R.L. Duble, and J.C. Thomas. 1977. Influence of management and season on fate of $\mathrm{N}$ applied to golf greens. Agron. J. 69:667-671.

Campbell, R. and R. Sargent. 2002. The perfect lawn; pursuit of Florida dreams fouls our waters. Orlando Sentinel. 16 June:A1.

Cotter, D.J. and F. Chavez. 1979. Factors affecting water application rates on urban landscapes. J. Amer. Soc. Hort. Sci. 104:189-191.

Diatloff, E. and Z. Rengel. 2001. Compilation of simple spectrophotometric techniques for the determination of elements in nutrient solutions. J. Plant Nutr. 24:75-86.

Dukes, M.D., L. Cardenas-Lailhacar, and G.L. Miller. 2005. Residential irrigation based on soil moisture. Resource Eng. Technol. Sustainable World. 12:4-6.

Erickson, J.E., J.L. Cisar, J.C. Volin, and G.H. Snyder. 2001. Comparing nitrogen runoff and leaching between newly established St. Augustinegrass turf and alternative residential landscape. Crop Sci. 41:1889-1895.

Garcia-Navarro, M.C., R.Y. Evans, and R.S. Montserrat. 2004. Estimation of relative water use among ornamental landscape species. Scientia Hort. 99:163-174.

Geron, C.A., T.K. Danneberger, S.J. Traina, T.J. Logan, and J.R. Street. 1993. The effects of establishment methods and fertilization practices on nitrate leaching from turfgrass. J. Environ. Qual. 22:119-125.

Gilman, E.F., R.J. Black, and B. Dehgan. 1998. Irrigation volume and frequency and tree size affect establishment rate. J. Arboricult. 24:1-9.

Gross, C.M., J.S. Angle, and M.S. Welterlen. 1990. Nutrient and sediment losses from turfgrass. J. Environ. Qual. 19:663-668.

Haman, D.Z., A.G. Smajstrla, and D.J. Pitts. 2005. Efficiencies of irrigation systems used in Florida nurseries. Univ. Fla. IFAS Coop. Ext. Serv. Bul. 312.

Howell, D.C. 2004. Fundamental statistics for behavioral sciences. Thomson Wadsworth, Stamford, CT.
Morton, T.G., A.J. Gold, and W.M. Sullivan. 1988. Influence of overwatering and fertilization on nitrogen losses from home lawns. J. Environ. Qual. 17:124-130.

Paine, T.D., C.C. Hanlon, D.R. Pittenger, D.M. Ferrin, and M.K. Malinoski. 1992. Consequences of water and nitrogen management on growth and aesthetic quality of drought-tolerant woody landscape plants. J. Environ. Hort. 10:94-99.

Pattanagul, W. and M.A. Madore. 1999. Water deficit effects on raffinose family oligosaccharide metabolism in coleus. Plant Physiol. 121:987-993.

Prevete, K.J., R.T. Fernandez, and W.B. Miller. 2000. Drought responses of three ornamental herbaceous perennials. J. Amer. Soc. Hort. Sci. 125:310-317.

Scheiber, S.M. and R.C. Beeson, Jr. 2006. Petunia growth and maintenance in the landscape as influenced by alternative irrigation strategies. HortScience 41:235-238.

Scheiber, S.M., E.F. Gilman, M. Paz, and K.A. Moore. 2007. Irrigation affects landscape establishment of burford holly, pittosporum, and sweet viburnum. HortScience 42:344 348.

Schulze, E.D., A.E. Hall, O.L. Lange, M. Evenari, L. Kappen, and U. Buschbom. 1980. Long-term effects of drought on wild and cultivated plants in the Negev desert. I. Maximal rates of net photosynthesis. Oecologia 45:11-18.

Snedecor, G.W. and W.G. Cochran. 1980. Statistical methods. 7th Ed. The Iowa State University Press, Ames, IA.

Snyder, G.H., B.J. Augustin, and J.M. Davison. 1984. Moisture sensor-controlled irrigation for reducing $\mathrm{N}$ leaching in Bermuda-grass turf. Agron. J. 76:964-969.

Stabler, L.B. and C.A. Martin. 2000. Irrigation regimes differentially affect growth and water use efficiency of two southwest landscape plants. J. Environ. Hort. 18:66-70.

White, R., R. Havlak, J. Nations, T. Pannkuk, J. Thomas, D. Chalmers, and D. Dewey. 2004 How much water is 'enough'? Using PET to develop water budgets for residential landscapes. Proc. Texas Sec. Amer. Water Works Assoc.

Zollinger, N., R. Kjelgren, T. Cerny-Koenig, K. Kopp, and R. Koenig. 2006. Drought responses of six ornamental herbaceous perennials. Scientia Hort. 109:267-274. 